\title{
Dermatitis herpetiformis: effect of gluten-free diet on skin IgA and jejunal structure and function
}

\author{
CHRISTINE I HARRINGTON, N W READ
}

British Medical fournal, 1977, 1, 872-875

\section{Summary}

To clarify the controversy about the effectiveness of a gluten-free diet in dermatitis herpetiformis, 10 highly motivated patients were investigated. The indices used to assess improvement included deposition of subepidermal IgA in unaffected skin, counts of intraepithelial lymphocytes, deposition of IgA in jejunal villi, and electrical tests of glucose absorption. In every patient subepidermal IgA concentrations fell after gluten withdrawal. In all but one patient the dose of dapsone necessary to control symptoms was reduced. Indeed, six patients stopped taking the drug completely within a year.

In nine patients biopsy specimens were taken from the jejunum; seven showed abnormalities in jejunal morphology, eight had increased numbers of intraepithelial lymphocytes, and five had increased numbers of IgAreactive cells in the lamina propria. Two of these three indices improved after gluten withdrawal, which confirmed that all nine patients were adhering to their diet.

Routine screening for malabsorption proved to be unsatisfactory for showing the mild jejunal disease found in patients with dermatitis herpetiformis. The electrical test of glucose absorption showed subnormal results in all eight patients tested, however, and in six the results improved after gluten withdrawal.

\section{Introduction}

Patients with dermatitis herpetiformis have changes in the jejunum similar to those in coeliac disease, ${ }^{1}$ but the effectiveness of gluten withdrawal is still disputed. ${ }^{2-5}$ We investigated the responses to gluten withdrawal in 10 highly motivated patients with dermatitis herpetiformis using more sensitive indices of improvement in the skin and jejunum than those that have been used before.

\section{Patients and methods}

Fifteen patients were considered for study but only the 10 (six men and four women) with subepidermal IgA in unaffected skin $^{6}$ were selected for the trial of gluten withdrawal. The 10 patients all had the typical rash of dermatitis herpetiformis, which responded to dapsone. The aims of the project were fully explained and informed consent obtained.

During the initial five-day admission jejunal biopsies, tests of bowel function, and skin biopsies were performed. The nature of the glutenfree diet was explained to patients and their relatives and the importance of rigid dietary control emphasised. Patients were advised to obtain a copy of the National Coeliac Society's handbook ${ }^{7}$ and contact the local society if problems arose. The diet was started only when the

Subdepartments of Dermatology and Gastroenterology, Academic Division of Medicine, University of Sheffield, Sheffield

CHRISTINE I HARRINGTON, MB, MRCP, senior registrar in dermatology N W READ, MB, MRCP, research registrar in gastroenterology lowest dose of dapsone that controlled symptoms had been established. All patients subsequently attended a special clinic every two months. This enabled them to compare progress and advise and encourage each other about the diet as well as enabling us to monitor the dose of dapsone. About six months after starting the diet the patients were readmitted and all the investigations were repeated.

Skin biopsy-Biopsy specimens of unaffected skin were obtained under local anaesthetic and frozen immediately. Sections were cut ( $4 \mu \mathrm{m}$ thick) on a cryostat at $-25^{\circ} \mathrm{C}$. Direct immunofluorescence was performed routinely ${ }^{8}$ using commercially available FITC-conjugated rabbit antihuman antisera for IgG, IgA, IgM, fibrin, and C3 and C4 (Behringwerke). The sections were mounted in buffered glycerol, examined using a fluorescent microscope (Leitz Orthoplan), and photographed with the attached Orthomat camera using an Ektachrome high-speed film (ASA 160).

Screening tests for malabsorption-Blood was collected and tested for haemoglobin, serum folate, and $B_{12}$. Faeces were collected for five days and the total fat content was estimated. A xylose-excretion test was carried out by estimating the amount excreted in the urine in the five hours after a $25-\mathrm{g}$ oral dose. Vitamin $\mathrm{B}_{12}$ absorption was assessed by means of a Schilling test (Dicopac; Radiochemical Centre, Amersham).

Immunological screening-The levels of serum immunoglobulins were estimated by automated immunoprecipitation. ${ }^{9}$ The presence or absence of antireticulin antibody was also determined by indirect immunofluorescence using rat liver. ${ }^{10}$ HLA tissue typing was performed by the microlymphocytotoxic method used in the Blood Transfusion Centre, Sheffield.

Intestinal intubation and biopsy-After an overnight fast each patient swallowed an intestinal tube which incorporated a biopsy capsule ${ }^{11}$ and channels for infusing and siphoning solutions. The capsule was checked radiologically to be about $5 \mathrm{~cm}$ beyond the duodenojejunal flexure. Electrical tests of glucose absorption were carried out by measuring the changes in transmural potential difference. ${ }^{12}{ }^{13}$ The method used continuous siphonage of solutions from the lumen in all except two patients (cases 1 and 2). From these data values of apparent $\mathrm{K}_{\mathrm{m}}$ (the Michaelis constant of absorption kinetics) for the electrogenic component of glucose absorption were determined by the direct linear plot. ${ }^{14}$ Before the tube was withdrawn a portion of jejunal mucosa was obtained from nine patients and divided into two after examination under a dissecting microscope. One piece was fixed, sectioned in the plane of the villi, and intraepithelial lymphocytes were counted ${ }^{15}$ on the tips and both sides of at least two villi. The counts were expressed as a percentage of the number of enterocytes in the same region (mean $( \pm \mathrm{SE}$ of mean) in controls $16 \pm 1)$. The other piece of tissue was examined by direct immunofluorescence for the presence of IgA, IgG, IgM, fibrin, and complement by an identical technique to that used for the skin biopsy. Jejunal morphology was graded according to the criteria of Alexander. ${ }^{16}$

\section{Results and comment}

Each patient reported an increase in energy and wellbeing after starting a gluten-free diet.

\section{SKIN}

After six months' gluten withdrawal subepidermal IgA deposition was reduced in every case (table I), becoming completely absent in two patients (cases 3 and 7). Most patients showed a change from the classical granular distribution of IgA to a more sparsely granular pattern or to an even more sparse or "speckled" pattern. It was notable, however, that in the two patients (cases 1 and 10) with antireticulin antibodies the IgA was deposited in a linear band (fig 1), which became granular after gluten withdrawal (fig 2).

The reduction in amounts of subepidermal IgA was accompanied by a decrease in the dose of dapsone necessary to control symptoms in 
TABLE I-Subepidermal IgA, antireticulin antibody, and jejunal findings before and after six months' treatment with gluten withdrawal. Second dose of dapsone is dose after one year, except in case 10 (after 6 months)

\begin{tabular}{|c|c|c|c|c|c|c|c|c|c|c|c|c|c|}
\hline \multirow{2}{*}{$\begin{array}{l}\text { Case } \\
\text { No }\end{array}$} & \multirow{2}{*}{$\begin{array}{l}\text { Age and } \\
\text { sex }\end{array}$} & \multicolumn{2}{|c|}{$\underset{\text { IgA }}{\text { Skin }}$} & \multicolumn{2}{|c|}{$\begin{array}{l}\text { Antireticulin } \\
\text { antibody }\end{array}$} & \multicolumn{2}{|c|}{$\begin{array}{c}\text { Dapsone dose } \\
\text { (mg/day) }\end{array}$} & \multicolumn{2}{|c|}{$\begin{array}{c}\text { Jejunal morphology } \\
\left(\mathrm{grade}^{*}\right)\end{array}$} & \multicolumn{2}{|c|}{$\begin{array}{l}\% \text { Of intraepithelial } \\
\text { lymphocytes }\end{array}$} & \multicolumn{2}{|c|}{$\begin{array}{l}\text { Gut IgA (No of cells } \\
\text { in lamina propria) }\end{array}$} \\
\hline & & Before & After & Before & After & Before & After & Before & After & Before & After & Before & After \\
\hline $\begin{array}{r}1 \\
2 \\
3 \\
4 \\
5 \\
6 \\
7 \\
8 \\
9 \\
10\end{array}$ & $\begin{array}{l}41 \mathrm{M} \\
46 \mathrm{M} \\
32 \mathrm{M} \\
67 \mathrm{~F} \\
34 \mathrm{~F} \\
40 \mathrm{M} \\
20 \mathrm{~F} \\
44 \mathrm{~F} \\
32 \mathrm{M} \\
33 \mathrm{M}\end{array}$ & $\begin{array}{c}\text { Linear } \\
\text { Granular } \\
\text { Granular } \\
\text { Granular } \\
\text { Granular } \\
\text { Granular } \\
\text { Granular } \\
\text { Granular } \\
\text { Granular } \\
\text { Linear }\end{array}$ & $\begin{array}{l}\text { Granular } \\
\text { Speckled } \\
\text { Absent } \\
\text { Speckled } \\
\text { Speckled } \\
\text { Speckled } \\
\text { Absent } \\
\text { Speckled } \\
\text { Speckled } \\
\text { Granular }\end{array}$ & $\begin{array}{l} \pm \\
= \\
= \\
= \\
= \\
= \\
+\end{array}$ & $\begin{array}{l}\overline{-} \\
\overline{-} \\
= \\
z \\
z \\
= \\
-\end{array}$ & $\begin{array}{r}100 \\
100 \\
50 \\
100 \\
50 \\
100 \\
150 \\
100 \\
100 \\
150\end{array}$ & $\begin{array}{c}50 \\
100 \\
0 \\
0 \\
0 \\
0 \\
0 \\
0 \\
12 \cdot 5 \\
100\end{array}$ & $\begin{array}{l}\text { II } \\
\text { II } \\
\text { IV } \\
\text { III } \\
\text { III } \\
\text { III } \\
\text { III } \\
\text { III } \\
\text { IV }\end{array}$ & $\begin{array}{l}\text { II } \\
\text { II } \\
\text { I } \\
\text { II } \\
\text { I } \\
\text { I } \\
\text { II } \\
\text { II } \\
\text { III }\end{array}$ & $\begin{array}{l}46 \\
43 \\
56 \\
62 \\
40 \\
48 \\
18 \\
50\end{array}$ & $\begin{array}{r}17 \\
36 \\
7 \\
32 \\
15 \\
31 \\
18 \\
22\end{array}$ & $\begin{array}{c}\text { Many } \\
\text { Many } \\
\text { Many } \\
\text { Many } \\
\text { Moderate } \\
\text { Moderate } \\
\text { Moderate } \\
\text { Few } \\
\text { Many }\end{array}$ & $\begin{array}{c}\text { Few }^{+} \\
\text {Few } \\
\text { Absent } \\
\text { Absent } \\
\text { Few } \\
\text { Few } \\
\text { Absent } \\
\text { Few }{ }^{\dagger} \\
\text { Few } \\
\text { Fen }\end{array}$ \\
\hline
\end{tabular}

*Alexander. ${ }^{16}$

†Also IgA deposition in region of villous basement membrane.

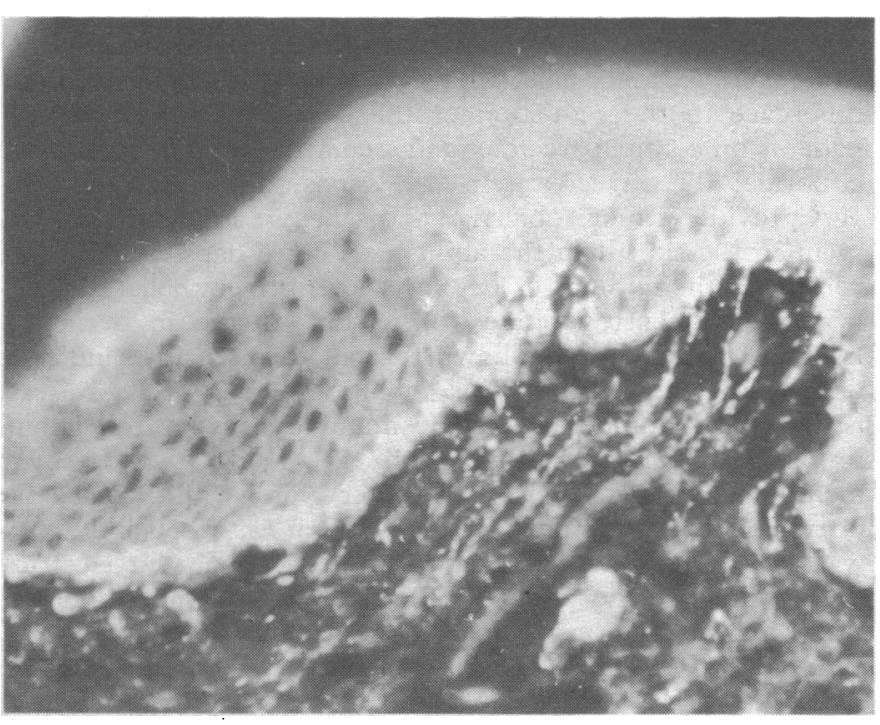

FIG 1-Case 1. Direct immunofluorescence of skin before gluten withdrawal showing linear IgA deposition beneath basement membrane of epidermis. $(\times 20$.

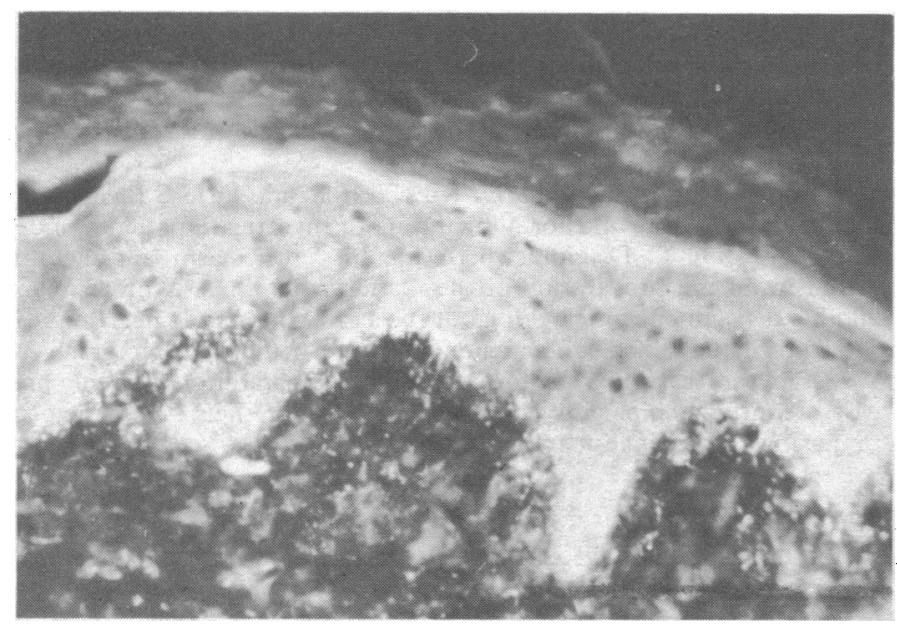

FIG 2-Case 1. Direct immunofluorescence of skin six months after gluten withdrawal showing granular subepidermal deposition of IgA. $(\times 18$.

nine out of 10 patients. Unlike Fry $e t a l^{2}$ we could reduce the dose of dapsone in most patients after two months' gluten withdrawal. Six patients stopped taking the drug within a year. In the two patients who showed complete loss of IgA from the skin dapsone was stopped within six months of starting the diet. Conversely, the dose of dapsone could not be significantly reduced in the two patients who had linear deposition of IgA in the skin.
GUT

Every patient showed morphological abnormality before gluten withdrawal and in seven out of nine cases there was improvement on diet (table I). The two patients (cases 1 and 2) with the least abnormality showed no improvement on gluten withdrawal and were unable to substantially reduce their dose of dapsone. They did, however, show reductions in the percentage of intraepithelial lymphocytes and in the numbers of IgA-containing cells in the lamina propria. Initially eight out of nine patients had large numbers of lymphocytes in the jejunal epithelium compared to control values $(16 \pm 1){ }^{15}$ These counts were reduced on the diet. The one patient with normal numbers of intraepithelial lymphocytes nevertheless showed abnormalities in jejunal morphology and several IgA reactive cells in the lamina propria, and the morphological features improved and IgA cells disappeared with treatment.

Immunofluorescence showed obvious IgA deposition in most biopsy specimens but no significant evidence of $\operatorname{IgG}, \operatorname{IgM}$, fibrin, and complement. Before gluten withdrawal IgA could be shown only in the cells of the lamina propria (fig 3). Many IgA reactive cells were noted in the patients with dense linear deposition of $\operatorname{IgA}$ in the skin (cases 1 and 10). Gluten withdrawal for six months reduced the numbers of IgA reactive cells in eight out of nine patients, and they completely disappeared in three (cases 3, 4, and 7). These patients included the two in whom IgA completely disappeared from the skin. One puzzling feature was the appearance of IgA in the basement membrane of the villi in five patients after gluten withdrawal (fig 4). Thus at least two out of the three indices used to assess the jejunal biopsy improved in every patient after gluten withdrawal.

The results of the screening tests for malabsorption were generally within normal limits (table II). The value of the standard xylose excretion test has been questioned, ${ }^{17}$ and in this study it yielded abnormal results in more patients after gluten withdrawal than before. In three patients initial high faecal fat excretion returned to normal on

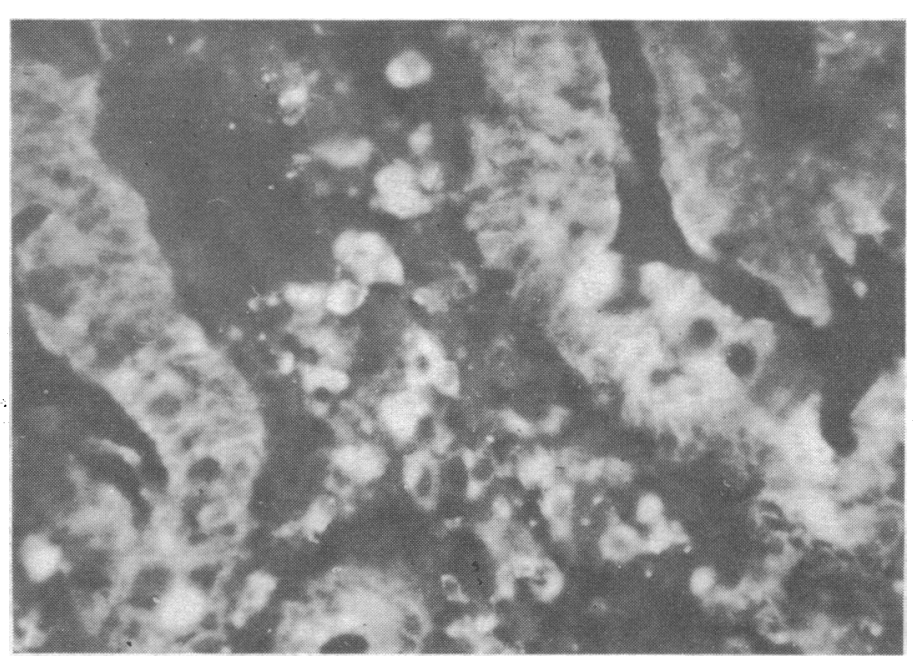

FIG 3-Case 6. Direct immunofluorescence of jejunum before gluten withdrawal showing many IgA reactive cells within lamina propria of villi. $(\times 30$. 


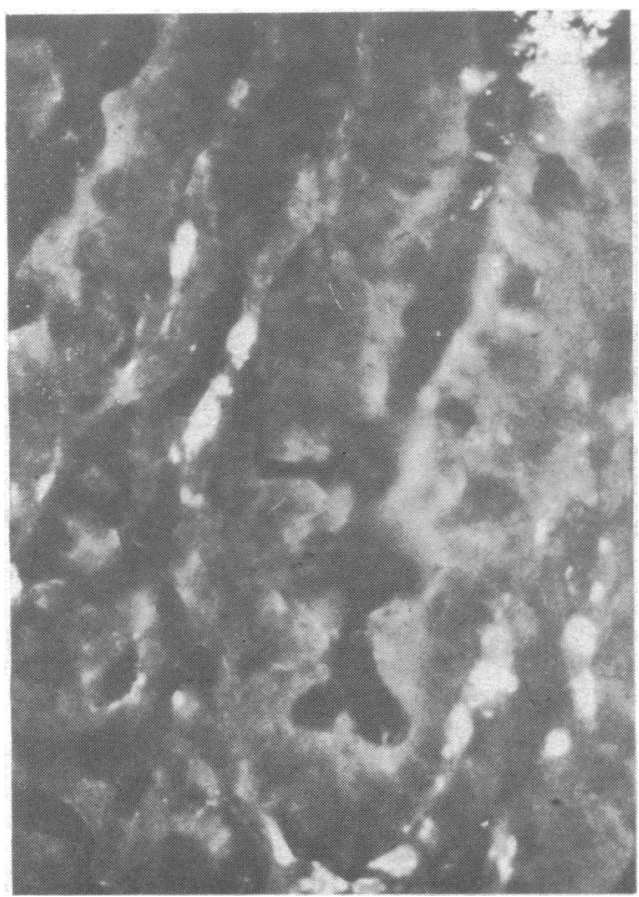

FIG 4-Case 6. Direct immunofluorescence of jejunum after gluten withdrawal showing IgA deposits in basement membrane region of villi but none within cells in lamina propria. $(\times 30$.

the diet but they were unable to significantly reduce the dose of dapsone (cases 1, 2, and 10).

The results of the electrical tests of glucose absorption (table II) yielded definitely subnormal values of apparent $\mathrm{K}_{\mathrm{m}}$ for the electrogenic component of glucose absorption in all patients tested. In the six patients investigated using continuous siphonage from the intestinal lumen the findings before treatment were similar to the values we have found in active coeliac disease $\mathrm{e}^{1318}$ and were significantly lower than those found in normal subjects. Withdrawing dietary gluten resulted in an increase in apparent $\mathrm{K}_{\mathrm{m}}$ in six out of eight patients, while one patient (case 8 ) showed a definite decrease. The modest increase in apparent $\mathrm{K}_{\mathrm{m}}$ after treatment in these patients compared with the values in patients with coeliac disease may be related to the shorter time on the diet.

\section{IMMUNOLOGICAL SCREEN}

There was no consistent pattern in the serum immunoglobulin concentrations. Nevertheless, the patient who had low levels of serum IgA both before and after gluten withdrawal (case 7) also showed no increase in intraepithelial lymphocytes but did show rapid and complete loss of IgA from both the gut and the skin after gluten withdrawal. Hence probably this patient belongs to the group with gluten enteropathy characterised by selective IgA deficiency. ${ }^{19} 20$
There was a high prevalence $(90 \%)$ of tissue antigen HLA-B8 in our patients compared with that in the population of the Sheffield area (28\% in a population sample of 3000 , data from the Blood Transfusion Centre, Sheffield) and also with that quoted in previous studies of dermatitis herpetiformis $(58-68 \%){ }^{21} 22$ This may have been due to the strict diagnostic criteria we used.

\section{Discussion}

We have shown that gluten withdrawal improves the skin, assessed by a decrease in the deposition of subepidermal IgA, of all patients with dermatitis herpetiformis. This is the first time that any form of treatment has been shown to influence subepidermal IgA deposition in dermatitis herpetiformis. Previously the response to gluten withdrawal has been assessed by the ability of the patients to reduce the dose of dapsone. Although most investigators have recorded improvement of the skin using this criterion, ${ }^{23-25}$ others have remained sceptical. ${ }^{34}$ Moreover, Heading et $a l^{5}$ noted that there was no significant difference in the reduction of the dose of dapsone between patients on a gluten-free diet and a control group of patients on a normal diet. Decrease in the deposition of subepidermal IgA provides a more objective and sensitive index of improvement in the skin than the ability to reduce dapsone. We have confirmed the findings of Fry ${ }^{15}$ that the intraepithelial lymphocytes are a sensitive index of jejunal disease in dermatitis herpetiformis. We have shown that another sensitive indicator of jejunal abnormality in this condition and in coeliac disease is the large number of IgA containing cells in the lamina propria. ${ }^{26}$ The appearance of IgA along the basement membranes of the jejunal villus after gluten withdrawal is an intriguing observation, which has not been described and clearly warrants further confirmation and investigation. Our electrical test of glucose absorptiơn ${ }^{12}{ }^{13}$ was the only functional index to show definite abnormalities in all the patients tested.

Although the strict criteria for selecting patients and the sensitivity of the tests used were certainly very important in assessing improvement in this study, the improvement in both skin and jejunum resulted from the strictness with which the patients adhered to the diet. The most important factor was their regular attendance at a special clinic, where they were seen by both a dermatologist and a gastroenterologist. Here they not only received dietary advice from the doctors and other patients but, more important, their enthusiasm was enhanced by seeing the increased wellbeing of other patients on the diet. Moreover, the reduction in the dose of dapsone provided both a definable goal and a yardstick against which to gauge their progress.

We thank Dr I B Sneddon, Dr R E Church, and Dr S S Bleehen for their helpful advice and for allowing us to investigate patients under their care; Dr C D Holdsworth for his enthusiasm and helpful criticism during preparation of the manuscript; Dr A Milford Ward and his department for carrying out the serum immunological studies; the staff of the Blood Transfusion Centre, Sheffield (Director Dr W Wagstaff), for carrying out tests for histocompatability antigens; and Miss Jennifer Senior and Miss Lisa Hartley for their skilled help in preparing specimens for immunofluorescence.

TABLE II-Results of tests of small-intestinal function before and six months after treatment

\begin{tabular}{|c|c|c|c|c|c|c|c|c|c|c|}
\hline \multirow{2}{*}{$\begin{array}{l}\text { Case } \\
\text { No }\end{array}$} & \multicolumn{2}{|c|}{$\underset{(\mu \mathrm{g} / \mathbf{l})}{\operatorname{Serum}}$} & \multicolumn{2}{|c|}{$\underset{(\mathrm{ng} / 1)}{\operatorname{Serum}} \mathrm{B}_{12}$} & \multicolumn{2}{|c|}{$\begin{array}{c}\text { 5-h Xylose excretion } \\
(\mathrm{mmol})\end{array}$} & \multicolumn{2}{|c|}{$\begin{array}{l}\text { Faecal fats } \\
(\mathrm{mmol} / 24 \mathrm{~h})\end{array}$} & \multicolumn{2}{|c|}{$\underset{(\mathrm{mmol})}{\mathrm{Km}_{\mathrm{m}}}$} \\
\hline & Before & After & Before & After & Before & After & Before & After & Before & After \\
\hline $\begin{array}{r}1 \\
2 \\
3 \\
4 \\
5 \\
6 \\
7 \\
8 \\
9 \\
10\end{array}$ & $\begin{array}{c}3 \cdot 8 \\
6.4 \\
2 \cdot 7 * \\
>20 \\
3 \cdot 2 \\
7 \cdot 2 \\
4.5 \\
5 \cdot 7 \\
3.2 \\
3.7\end{array}$ & $\begin{array}{c}8 \cdot 3 \\
9 \cdot 9 \\
5 \cdot 5 \\
>20 \\
15 \\
9 \cdot 3 \\
5 \cdot 8 \\
9 \cdot 1 \\
9 \cdot 6 \\
2.5^{*}\end{array}$ & $\begin{array}{l}339 \\
340 \\
184 \\
163^{*} \\
286 \\
503 \\
381 \\
387 \\
661 \\
375\end{array}$ & $\begin{array}{l}266 \\
396 \\
425 \\
938 \\
248 \\
709 \\
363 \\
536 \\
475 \\
480\end{array}$ & $\begin{array}{l}40 \\
32 \\
27^{*} \\
29 \\
16^{*} \\
49 \\
42 \\
13 \cdot 2^{*} \\
49 \\
40\end{array}$ & $\begin{array}{l}24^{*} \\
39 \\
21^{*} \\
29 \\
23^{*} \\
27 \\
13 \cdot 3^{*} \\
21^{*} \\
73^{*}\end{array}$ & $\begin{array}{c}24 \cdot 3 * \\
38 \cdot 1^{*} \\
5 \cdot 3 \\
7 \cdot 5 \\
8 \cdot 8 \\
11 \cdot 9 \\
8 \cdot 5 \\
6 \cdot 0 \\
6 \cdot 2 \\
35 \cdot 7^{*}\end{array}$ & $\begin{array}{l}12 \\
15 \cdot 9 \\
5 \cdot 3 \\
12 \\
11 \\
20 \cdot 9 \\
6 \cdot 6 \\
6 \cdot 6 \\
8 \cdot 1 \\
17\end{array}$ & $\begin{array}{r}30 \dagger \\
27 \dagger \\
17 \\
15 \\
13 \\
12 \\
8 \\
11\end{array}$ & $\begin{array}{c}27 \dagger \\
44 \dagger \\
21 \\
23 \\
40 \\
15 \\
13 \\
6\end{array}$ \\
\hline
\end{tabular}

*Abnormal results. †Apparent $\mathrm{Km}$ was obtained with a different method ${ }^{13}$ from that used in other patients. Therefore values are slightly higher.

Conversion: SI to traditional units-Xylose: $1 \mathrm{mmol} / 5 \mathrm{~h} \approx 15 \mathrm{mg} / 100 \mathrm{ml}$. Faecal fats (as stearic acid): $1 \mathrm{mmol} / 24 \mathrm{~h} \approx 0.28 \mathrm{~g} / 24 \mathrm{~h}$. 
Requests for reprints should be addressed to Dr C I Harrington, Rupert Hallam Department of Dermatology, Hallamshire Hospital, Glossop Road, Sheffield S10 2JF.

\section{References}

${ }^{1}$ Marks, J, Shuster, S, and Watson, A J, Lancet ${ }^{\xi}$, 1966, 2, 1280.

2 Fry, L, et al, Lancet, 1973, 1, 288.

${ }^{3}$ Marks, J, and Shuster, S, British Medical fournal, 1970, 1, 498

4 Weinstein, W M, et al, Gastroenterology, 1971, 60, 362.

${ }^{5}$ Heading, R C, et al, British fournal of Dermatology, 1976, 94, 509.

${ }^{6}$ Fry, L, and Seah, P P, British fournal of Dermatology, 1974, 90, 137.

' Nilson, B, (editor), Coeliac Handbook. London, Coeliac Society, 1970.

${ }^{8}$ Beutner, E H, Chlorzelski, T P, and Jordon, R E, Autosensitisation in Pemphigus and Bullous Pemphigoid, p 111. Springfield, Thomas, 1970.

${ }^{9}$ Ritchie, R F, et al, American fournal of Clinical Pathology, 1973, 59, 151.

10 Seah, P P, et al, Lancet, 1971, 1, 834

${ }^{11}$ Crosby, W H, and Kugler, H W, American fournal of Digestive Diseases, 1957, 2, 236.

12 Read, N W, Holdsworth, C D, and Levin, R J, Lancet, 1974, 2, 624
13 Read, N W, et al, Gut, in press.

${ }^{4}$ Eisenthal, R, and Cornish-Bowden, A, Biochemical fournal, 1974, 139, 715.

${ }^{15}$ Fry, L, et al, fournal of Clinical Pathology, 1974, 27, 817.

${ }^{16}$ Alexander, J O'D, Dermatitis Herpetiformis, p 236. London, Saunders, 1975.

1: Sladen, G E, and Kumar, P J, British Medical fournal, 1973, 3, 223.

18 Read, N W, Holdsworth, C D, and Levin, R J, European fournal of Clinical Investigation, 1976, 4, 311 .

${ }^{19}$ Crabbe, P A, and Heremans, J F, American fournal of Medicine, 1967, $42,319$.

${ }^{20}$ Hobbs, J R, Lancet, 1968, 1, 110

21 Gebhard, R L, et al, Lancet, 1973, 2, 760.

${ }^{22} \mathrm{Katz}, \mathrm{I}$, et al, fournal of Clinical Investigation, 1972, 51, 2977.

${ }^{23}$ Fry, L, et al, Lancet, 1968, 1, 557.

${ }^{24}$ Staak, W J B M, van der, et al, Dermatologica, 1970, 140, 231.

${ }^{25}$ Blomquist, K, Jussila, J, and Tarpila, S, Archives Belges de Dermatologie et Syphilagraphie, 1970, 26, 171.

${ }^{26}$ Lancaster-Smith, M, et al, Gut, 1974, 15, 371.

27 Brandtzaeg, P, and Baklien, K, Scandanavian fournal of Gastroenterology, 1976, 11, suppl No 36, p 5.

(Accepted 1 February 1977)

\title{
CONDENSED REPORT
}

\section{Long-term treatment of acromegaly with bromocriptine}

\author{
J A H WASS, M O THORNER, D V MORRIS, LESLEY H REES, A STUART MASON, \\ A E JONES, G M BESSER
}

British Medical fournal, 1977, 1, 875-878

\begin{abstract}
Summary
Seventy-three patients with active acromegaly were treated for three to 25 months with bromocriptine $10-60 \mathrm{mg} /$ day. Seventy-one patients showed symptomatic and objective clinical improvement. This included reduction in excessive sweating, hand and foot size, and the number of headaches; improved facial appearance; and increased energy and libido. Abnormal visual fields became normal in two patients, one of whom had concomitant radiotherapy. Mean circulating growth hormone levels, obtained by averaging serial samples through the day, fell by more than $7 \mu \mathrm{g} / 1$ or became undetectable in 58 patients $(79 \%)$ but did not reach normal values: only 15 patients had mean levels on treatment of $5 \mu \mathrm{g} / 1$ or less. Twenty-three patients were diabetic before treatment, and glucose tolerance became normal in 15 and improved in a further five. Provided the drug was started slowly side effects were minor when compared with the considerable clinical benefit obtained.
\end{abstract}

Departments of Endocrinology, Chemical Pathology, and Radiotherapy, St Bartholomew's Hospital, London EC1A 7BE

J A H WASS, MB, MRCP, MRC fellow

M O THORNER, MB, MRCP, lecturer

LESLEY H REES, MD, MRCP, senior lecture

A E JONES, MD, FRCP, professor of radiotherapy

G M BESSER, MD, FRCP, professor of endocrinology

Department of Metabolism and Endocrinology, London Hospital, London E1 1BB

D V MORRIS, MA, MRCP, lecturer

A STUART MASON, MD, FRCP, consultant physician
Two patients died while they were taking bromocriptine, but the deaths were not thought to have been caused by the drug.

Bromocriptine offers a major advance in the medical management of acromegaly, but further careful followup is required to determine whether serious side effects will be a problem with the long-term use of high doses.

\section{Introduction}

Bromocriptine is a long-acting dopamine agonist which raises serum growth hormone (GH) levels in normal subjects but, paradoxically, lowers them in acromegalic patients. ${ }^{12}$ We have described the short-term biochemical and clinical benefits of bromocriptine in acromegaly, ${ }^{3}$ and these early results have been confirmed by others. ${ }^{4-6}$

We report here our experience of treating 73 patients with bromocriptine for 3 to 25 months (mean $12 \cdot 8$ months). Fortyfive were treated for 12 months or more. We examined the clinical changes on treatment and how these related to $\mathrm{GH}$ suppression during long-term management.

\section{Patients and methods}

Seventy-three acromegalic patients ( 48 men) aged $18-72$ years were treated with bromocriptine. All gave their informed consent to the studies. Active acromegaly had been clinically diagnosed two weeks to 28 years before they started bromocriptine and was confirmed at the time of starting treatment by lack of suppression of circulating GH to less than $2 \mu \mathrm{g} / 1$ during a $50-\mathrm{g}$ oral glucose tolerance test. Forty-two patients also had their pituitary tumours treated by external irradiation, which was carried out from 28 years before to five months after starting bromocriptine; in 15 patients irradiation had been performed at least three years earlier. Five patients had also been treated by partial hypophysectomy and one by yttrium implantation two to 12 years before drug treatment. Twenty-five patients had had no other 